American Journal of Pharmaceutical Education 2018; 82 (7) Article 6804.

\title{
COMMENTARY
}

\section{Curricular Reform in Pharmacy Education Through the Lens of the Flexner Report of 1910}

\author{
Ryan L. Crass, PharmD, ${ }^{\text {a }}$ Frank Romanelli, PharmD, $\mathrm{MPH}^{\mathrm{b}, \mathrm{c}}$ \\ ${ }^{a}$ University of Michigan College of Pharmacy, Ann Arbor, Michigan \\ ${ }^{\mathrm{b}}$ University of Kentucky College of Pharmacy, Lexington, Kentucky \\ ${ }^{c}$ Executive Associate Editor, American Journal of Pharmaceutical Education, Arlington, Virginia
}

Submitted September 21, 2017; accepted June 5, 2018; published September 2018.

\begin{abstract}
Abraham Flexner's 1910 report on medical education in the United States (US) and Canada propelled medical training forward into a contemporary renaissance. The report heralded many seismic changes that still resonate within medical and health professions education throughout the US. Today several factors are accelerating curricular reform within pharmacy education, including but not limited to accreditation standards, technologic advances, and student diversity. Despite the fact that Flexner's report is now over a century old, many of his observations and recommendations regarding education are as pertinent and timely today as they were in 1910. This commentary will discuss and reflect upon curricular reform in pharmacy education as it contrasts with some of the observations, findings, and recommendations of Flexner's 1910 report.
\end{abstract}

Keywords: curriculum, pharmacy education, medical education

\section{INTRODUCTION}

In 1987, Eldredge and Gould postulated the punctuated equilibrium model of evolution as an alternative to phyletic gradualism. ${ }^{1}$ This model describes evolution as a process characterized by large periods of stasis punctuated by the abrupt appearance of multiple new species. In contrast, the gradualist theory of Darwinian evolution suggests that speciation occurs due to accumulation of new traits at a constant rate within a population over time. ${ }^{1}$ These theories of evolutionary biology may seem distant to pharmacy education, yet they are instructive when applied to the concepts of curricular development and reform. While pharmacy educators may describe curricular development as a gradual and constant process leading to continuous improvement in the quality of pharmacy education, it may be better described and characterized by periods of stasis punctuated by major reformation.

Doctor of Pharmacy (PharmD) curricula are at a point of rapid evolution due to, among other things, pressures from the Accreditation Council for Pharmacy Education (ACPE), advances in technology, and an ever changing base of prospective students with diverse learning experiences. ${ }^{2,3}$ As pharmacy education approaches a period of rapid innovation and evolution, it is beneficial to step back and examine developments through the clarifying

Corresponding Author: Ryan L. Crass, University of

Michigan College of Pharmacy, 428 Church St., Ann Arbor, MI 48109. E-mail: rcrass@med.umich.edu lens of history. The primary event that punctuated the previous equilibrium in medical education was Abraham Flexner's 1910 report on medical education in the United States (US) and Canada. ${ }^{4}$ The goal of this work is to provide a perspective on curricular reform in pharmacy and medicine through the lens of Flexner's landmark report, which was critical in shaping contemporary medical and pharmacy education, yet still contains many observations relevant to the challenges and opportunities of today.

\section{HISTORY}

The practice of medicine was changing rapidly in the century prior to Flexner's assessment of medical education. ${ }^{5}$ Advances in scientific knowledge - such as the understanding of bacteria as agents of disease, the development of clinical pathology, and the resulting adoption of aseptic surgical technique - led to an improved ability of physicians to diagnose and treat disease with a resulting shift away from the practice of empiricism. ${ }^{5}$ Medical education, in the wake of this scientific revolution, likewise shifted from individual apprenticeships to schools of medicine. ${ }^{6}$ Formal medical education began with lectures in anatomy and physiology, designed to supplement the learning of physician's apprentices, but soon grew to replace experiential learning with "didactic lectures given in huge, badly lighted amphitheaters. $"$ ",5

By the turn of the $20^{\text {th }}$ century, medical education was beginning to change. The American Medical Association (AMA) and the Association of American Medical Colleges 


\section{American Journal of Pharmaceutical Education 2018; 82 (7) Article 6804.}

(AAMC) began to set standards for medical education and state medical licensing boards were created and given the power to deny licensure to graduates not meeting certain standards. ${ }^{5}$ Yet despite these advancements, progress was gradual. A major event was required to catalyze the creation of a new "species" of medical schools. Enter Abraham Flexner, an outsider with a background in education rather than medicine. ${ }^{6}$ In a Herculean effort lasting just 16 months, Flexner visited 98 cities and all 155 medical schools in the US and Canada. ${ }^{7}$ His report shaped medical, and by extension, pharmacy education as it exists today.

Similar to medicine, the profession of pharmacy began as a system of apprenticeship. ${ }^{8}$ During the early $20^{\text {th }}$ century, remnants of the apprenticeship system continued with students and graduates often required to complete a requisite period of practice experience under a practitioner, either while enrolled or upon graduation. The experiential requirements of today are a vestige of this original apprenticeship model. The Philadelphia College of Pharmacy, established in 1821, was the first formal college organized to train pharmacists. Pharmacists founded the college to prevent physicians from establishing programs where physicians (rather than pharmacists) would control instruction of student pharmacists. Most of early pharmacy-based educational institutions were primarily centered in urban areas and were privately owned and operated. The first public institution to offer a pharmacy program was the University of Michigan in 1860. During World War II many private programs encountered financial difficulties due to drops in enrollment, which required many of these programs to join with academic health centers beginning to appear across the US to remain sustainable.

Degrees in pharmacy have varied from the Graduate in Pharmacy (Ph.G.), to the Pharmaceutical Chemist (Ph.C.), to the now terminal Doctor of Pharmacy (PharmD) degree. The original accrediting body for pharmacy, the American Council on Pharmaceutical Education, was established in 1932 to set standards for a baccalaureate degree in pharmacy. The name changed to the Accreditation Council for Pharmacy Education in 2003. In the 1940s, a four-year baccalaureate degree became the norm across pharmacy practice. Subsequently, the American Council on Education proposed that the profession adopt a six-year entry-level curriculum. Met with resistance, a compromise was struck and the five-year Bachelor of Science degree in Pharmacy was adopted as the entrylevel degree for the profession. A two-year post-graduate PharmD, which emphasized clinical practice, would soon after be offered by a few schools. Collaterally occurring at this time was the emergence of several postgraduate residency training programs. Driven in part by a shift from product- to patient-oriented practice and the introduction of the concept of pharmaceutical care, the profession moved to establish a six-year PharmD degree as the entry-level practice credential beginning in $2000 .^{9}$

\section{DRIVERS OF CURRICULAR REFORM}

In 1905, five years prior to Flexner's report, both the AAMC and AMA issued standards for medical schools. ${ }^{5}$ Flexner recognized the importance of accrediting bodies and licensing organizations in driving change. The role of state boards also received an entire chapter in his report where he states that they "are the instruments through which the reconstruction of medical education will be largely effected." 4 Standards for PharmD curricula are set by ACPE and are updated in eight-year cycles, most recently in $2016 .{ }^{10}$ These standards drive curricular development and evolution through mandated compliance to retain full accreditation. Earlier iteration of accreditation standards placed greater emphasis on "products" rather than "patients." These standards have evolved with the practice of pharmacy and an increasing focus is now placed on the provision of patient care. The Standards 2016 emphasize preparation of PharmD graduates to be "practice-ready" and "team-ready." In turn, colleges and their respective curriculum committees are charged to develop innovative interprofessional educational experiences (Standard 11), integrate experiential education with didactic coursework (Standards 12 and 13), and use more authentic and comprehensive means of student assessment (Standards 24 and 25). ${ }^{10}$ Interprofessional education (IPE) curricula challenge health professional schools, traditionally operating in silos, to collaborate in a manner reflective of clinical practice. Early and integrated introductory pharmacy practice experiences (IPPEs) provide one mechanism for exposing students to interprofessional practice, but create the challenge of balancing the time commitments of experiential and foundational didactic coursework. Finally, pharmacy schools are required to assess the readiness of students to progress through the curriculum, and the performance of the didactic curriculum in building foundational knowledge. The latter must be accomplished, in part, through administration of the Pharmacy Curriculum Outcomes Assessment (PCOA) examination. While accreditation standards drive curricular reform, critics often cite these imperatives as potentially stymieing innovation or creating a "one-size-fits all" paradigm that limits creativity in curricular design.

Educators and non-educators alike can agree that rapid advances in technology have affected education. In his report, Flexner noted how "the self-registering thermometer, the stethoscope, the microscope, the correlation of observed symptoms with the outgivings of chemical 


\section{American Journal of Pharmaceutical Education 2018; 82 (7) Article 6804.}

analysis and biological experimentation, enormously extend the physician's range." 4 These technologies were revolutionizing the practice of medicine and therefore required a revolution in the delivery of medical education. The lecture hall, however, remained largely unchanged from the beginning to the end of the $20^{\text {th }}$ century. The primary technologic advancement during this period was the ability to project content onto a screen. The college classroom has changed dramatically and collaterally with the rapid advancement of technology and its ability to alter the delivery of information from teacher to learner. The pharmacist of today spends a significant portion of his or her workday in front of a computer screen. Likewise, the student pharmacist of today spends much of his or her class time in front of a personal tablet or laptop computer. Foundational knowledge in all subjects is readily available to learners over the internet, and the sheer volume of this information and the speed with which it can be accessed has undermined the traditional instructional delivery model where the learned professor passively delivers knowledge through didactic lecture. Technology now allows for rapid, automatic, and almost seamless lecture capture and dissemination at little cost to either the instructor or the institution. A 2014 survey investigating the effect of lecture-capture technology found that while less than $10 \%$ of pharmacy students reported using lecture capture as a replacement for live lecture, $69 \%$ of faculty felt that lecture capture had affected classroom attendance. ${ }^{11}$ A similar study of firstand second-year medical students found that $44 \%$ of students preferred recorded lectures to attending live lecture. ${ }^{12}$ Interestingly, the proportion who preferred recorded lectures appeared to significantly increase from the first (33\%) to second $(57 \%)$ professional years $(p<.001)$. These reports suggest that a large proportion of students may not find value in traditional lectures that simply involve delivering foundational knowledge, and so choose to view and review this content on their own at a time and place of their choosing.

The final driver of curriculum reform is the group most affected by the curriculum itself, the students. As highlighted in the aforementioned section, the pharmacy student of today is a member of an increasingly diverse group of learners, who were raised with advanced technologic devices and systems both in and outside of the classroom. These students, therefore, may be dissatisfied with traditional models of instructional delivery that are inconsistent with or fail to use advanced technologic options at least in part. ${ }^{13}$ Most pharmacy students of today acquired foundational knowledge in primary, secondary, and undergraduate classrooms that more routinely incorporate technology in innovative ways to promote learning. Most pharmacy educators, however, may not have been trained in conjunction with most of the advanced technologic options available today. Faculty may recall furiously taking notes as their predecessors lectured with the aid of blackboard figures or overhead projectors. This disconnect between generations of learners and educators may lead to angst as technologies, such as personal laptop computers and lecture capture, appear to undermine student attendance both to content and class itself. Additionally, use of laptop computers in-class has been demonstrated to increase student distraction and negatively impact learning outcomes. ${ }^{14,15}$ Faculty may also philosophically believe that there is inherent value in the physical presence of students within a lecture hall engaged in the exercise of non-computer assisted note-taking. ${ }^{16}$ These data and preferences have led some educators to ban the use of these technologies with the goal of decreasing student distraction and increasing attendance. ${ }^{17}$ While it is certainly true that technology makes distraction as easily accessible as useful information, it is also essential if not primal to the way in which many current students approach learning. ${ }^{18,19}$ The 2017 EDUCAUSE Center for Analysis and Research (ECAR) study surveyed over 40,000 undergraduate students at 124 institutions regarding their engagement with technology and found that across the board, on average, students wished their instructors used technology to a greater extent in their classes. ${ }^{19}$ If students find more value in checking email and social media during lecture, at least some culpability may lie with the lecturer in failing to design course content that is engaging to a new generation of learner.

\section{COMPONENTS OF REFORMED CURRICULA}

Pharmacy curricula emphasize the importance of evidence-based pharmacotherapeutic decision-making, and yet some pharmacy educators have been slow to integrate methodologies shown to improve learning outcomes. ${ }^{20}$ Active learning strategies focus on engaging students in the learning process by challenging them to assimilate and apply foundational information thereby promoting critical thinking and lasting learning. Multiple strategies have been proposed and tested including cooperative, team-based, problem-based, and case-based learning approaches. ${ }^{20}$ Many of these strategies benefit from the "flipped classroom" approach, which leverages technology to offload foundational information into content delivered before the in-class lecture period ("pre-class") freeing up time in class for critical thinking, practical application, and problem solving. ${ }^{21}$ Case- and problem-based learning strategies employing a "flipped-lecture" format have been successfully employed in self-care, pharmaceutics, and therapeutics courses. ${ }^{22-26}$ Team-based active 


\section{American Journal of Pharmaceutical Education 2018; 82 (7) Article 6804.}

learning methodologies have been effectively implemented in courses dealing with patient assessment, self-care, therapeutics, and pharmacokinetics. ${ }^{26-34}$

Additionally, many colleges and schools have moved toward integrated curricula, which intermingle the teaching of both the basic and clinical sciences. This amalgamation is intended to enhance the logical and ordered presentation of concepts and facilitate learning and memory. ${ }^{35}$ Faculty should be encouraged and allowed to experiment and innovate to continuously engage diverse groups of students. Various novel strategies reported in the literature include film making, comic book creation, interpretive dance, TED talks, and serious games or gamifications. ${ }^{36-38}$ Flexner noted in the early 1900 s that "out-and-out didactic treatment is hopelessly antiquated; it belongs to an age of accepted dogma or supposedly complete information, when the professor "knew" and the students "learned." The lecture indeed continues of limited use."4 Unfortunately, it has taken over a century for medical and pharmacy educators to begin to move away from this convention toward active learning modalities supported by evidence-based educational science and the neurobiology of learning. ${ }^{39}$

Flexner also recognized the value of experiential learning within medical curricula. He noted that while the apprenticeship system was no longer practical given the burgeoning science of medicine, removing students from direct preceptorship and from direct patient contact negatively affected learning. He felt that "under any but the most vigorous teaching, the demonstrative method may fail to stimulate sufficiently: the student looks and listens, - a passive attitude that may relapse into something more deeply negative." ${ }^{4}$ His opinion was that didactic curriculum "has no right to forestall experience, filling the student with ill comprehended notions of what he is going some time to perceive" and that "the student is to collect and evaluate facts. The facts are locked up in the patient. To the patient, therefore, he must go."4

Experiential education in pharmacy consists of both IPPEs that are completed prior to the final professional year and often concurrently with didactic instruction, and advanced pharmacy practice experiences (APPEs). Early integration of experiential education into the curriculum creates an opportunity for students to participate in patient care, gain experience with the interface between drugs and disease states in practice, and to work in collaborative care settings. These experiences provide context and a framework upon which foundational knowledge can be organized during and after didactics. Long-term learning is difficult without a conceptual framework and understanding of future use and applications. Flexner emphasized that "description is no substitute for tactile and visual experience, and that such experience, if intelligently controlled, both records and organizes itself with surprisingly little formal revamping." 4 Additionally, early experiential education may energize and excite students regarding the content to be covered in didactic courses. As expressed by Flexner, "there is no cement like interest, no stimulus like the hint of a coming practical application." 4 For these reasons, Standards 2016 emphasizes the integration of experiential and didactic educational experiences. ${ }^{10}$ The experiential curriculum should be designed to engage the student early and to build on previous experiences toward an understanding of the pharmacist's role in multiple patient care settings.

Health care systems are increasingly complex and require collaborative interaction among all players in the delivery process to increase patient safety and overall quality of care. Pharmacists are no longer practicing in silos intimately tied to drug preparation and distribution. Many contemporary pharmacy practice settings involve very little direct interaction with drug product but involve a greater focus on cognitive services. To function optimally in such an environment, pharmacists must understand the role(s) and expertise of each member of the care team and be as proficient in interprofessional communication as they are in pharmacotherapeutic knowledge. However, traditional curricula at many pharmacy colleges do not expose student pharmacists to other health professional students until the final professional year. Reformed curricula should emphasize early interprofessional education, both in didactic and experiential coursework, to foster understanding and encourage communication and collaboration prior to licensure. ACPE Standards 2016 highlight interprofessional team dynamics, interprofessional education, and interprofessional practice as core elements for curricular development. ${ }^{10}$ Pharmacy schools have been challenged in developing curricula that model the kind of collaboration they are hoping to instill in students. Interprofessional goals can only be accomplished by partnering with other health professional schools including medicine, nursing, physical therapy, occupational therapy, dietetics, social work, etc. Although there are certainly challenges and barriers to the creation of interprofessional experiences, the potential benefits for students and patients are apparent with interprofessional curricula demonstrating improvements in team communication, knowledge, and skills between students within the various health professions. ${ }^{40}$

\section{DISCUSSION}

Pharmacy education has reached a nexus of curricular evolution driven by pressure from the rapid advancement and integration of technology in the clinic and the 


\section{American Journal of Pharmaceutical Education 2018; 82 (7) Article 6804.}

classroom, an increasingly diverse student body, and the goals outlined within ACPE Standards. Evolved curricula emphasize the importance of active learning in the classroom and early integration of interprofessional clinical environments with didactics to develop critical thinking skills and facilitate the creation of a framework for lifelong learning and scientific inquiry. Although the landscape of medicine and pharmacy is vastly different than it was over a century ago, many of the pedagogical recommendations from the Flexner Report of 1910 remain relevant and strikingly incompletely implemented.

Flexner's assessment of medical education in the early 1900 s provided the catalyst for the last major evolution of medical education. His vision for the future was built upon the scientific method and the physician scientist, who he outlined as a clinical investigator who found inspiration for research in the routine care of his or her patients. ${ }^{41}$ However, his seminal report is at times criticized for leading to the research-driven culture of modern academia in medicine and pharmacy; a culture that rewards research at the expense of clinical teaching. ${ }^{41}$ Yet Flexner was an educator, not a physician or natural scientist, and his report offers teaching advice that is fundamentally consistent with the prevailing ideas of today. He was a strong proponent of the integration of patient care and clinical teaching, which he saw as the merits of the apprenticeship system, and vehemently opposed the pure didactic lecturing, which was pervasive at the time. He was also a firm believer in active learning strategies as a method to inspire critical thinking and promote lasting learning. His belief was that "on the pedagogic side, modern medicine, like all scientific teaching, is characterized by activity. The student no longer merely watches, listens, memorizes; he does."4

Education in medicine and pharmacy is currently poised for a renaissance built upon the opportunities provided by technology and the increasingly interprofessional nature of clinical care. Successfully reformed curricula will promote active learning in the classroom while offloading foundational information using technology, engage students in early experiential education, create opportunities to foster interprofessionalism, promote scientific inquiry and lifelong learning, and assess students on the skills they will need to be successful as modern pharmacists. While the punctuated equilibrium does not completely explain the evolution of species, neither should we allow it to continue to define curricular development in pharmacy education. Schools and colleges of pharmacy and academicians must invest in educational scholarship to create an evidence-based, gradualist evolution of teaching and learning in the modern era of rapid creation and dissemination of knowledge and changing interactions with technology. Finally, the perceptions of an outsider were necessary to revolutionize medical education at the turn of the $20^{\text {th }}$ century. Similarly, pharmacy colleges should look to other areas of education, namely, primary and secondary education, for insights in how to engage students in active learning.

\section{CONCLUSION}

Abraham Flexner's report on medical education in the United States and Canada shaped the landscape of education in medicine and pharmacy for over a century following its publication in 1910. Although pharmacy educators must look toward a future shaped by technology and the modern student, it is important to consider the lessons learned from the last great period of reform in health education. Through an investment in educational scholarship and continuous quality improvement, modern curricular development will be able to take on a pattern of gradualist evolution and will cease to be defined by periods with minimal innovation punctuated by rapid reformation.

\section{REFERENCES}

1. Eldredge N, Gould SJ. Punctuated equilibria: an alternative to phyletic gradualism. In: Schopf TJM, ed. Models in Paleobiology. San Fransisco, CA: Freeman Cooper; 1972:82-115.

2. Romanelli F.Flexner, Educational reform, and pharmacy. Am J Pharm Educ. 2017;81(2):Article 21.

3. Selingo JJ. 2026, The Decade Ahead. The Seismic Shifts Transforming the Future of Higher Education. Washington, DC: The Chronicle of Higher Education; 2016:1-44. http://www.uky.edu/ universitysenate/sites/www.uky.edu.universitysenate/files/TheDecade-Ahead-Chronicle-of-Higher-Education1.pdf. Accessed January 20, 2018.

4. Flexner A. Medical Education in the United States: A Report to the Carnegie Foundation for the Advancement of Teaching. New York, NY: The Carnegie Foundation; 1910.

5. Barzansky B. Abraham Flexner and the era of medical education reform. Acad Med. 2010;85(9 Suppl):S19-S25.

6. Ludmerer KM. Commentary: understanding the Flexner report. Acad Med. 2010;85(2):193-196.

7. Markel H. Abraham Flexner and his remarkable report on medical education: a century later. JAMA. 2010;303(9):888-890.

8. Fink JL. Pharmacy: a brief history of the profession. Student Doctor Network. https://www.studentdoctor.net/2012/01/pharmacya-brief-history-of-the-profession/. Updated January 11, 2012.

Accessed January 22, 2018.

9. Hepler CD, Strand LM. Opportunities and responsibilities in pharmaceutical care. Am J Hosp Pharm. 1990;47(3):533-543.

10. Accreditation Council for Pharmacy Education. Accreditation standards and key elements for the professional program in pharmacy leading to the doctor of pharmacy degree. https://www. acpe-accredit.org/pdf/Standards2016FINAL.pdf. Accessed June 29, 2017.

11. Marchand JP, Pearson ML, Albon SP. Student and faculty member perspectives on lecture capture in pharmacy education. Am J Pharm Educ. 2014;78(4):Article 74. 


\section{American Journal of Pharmaceutical Education 2018; 82 (7) Article 6804.}

12. Gupta A, Saks NS. Exploring medical student decisions regarding attending live lectures and using recorded lectures. Med Teach. 2013;35(9):767-771.

13. Kvavik R. Convenience, communications, and control: how students use technology. In: Oblinger DG, Oblinger JL, eds. Educating the Net Generation: EDUCAUSE; 2005:7.1-7.20. 14. Hembrooke H, Gay G. The laptop and the lectuer: the effects of multitasking in learning environments. J Comput High Educ. 2003;15(1):46-64.

15. Fried CB. In-class laptop use and its effects on student learning. Comput Educ. 2008;50(3):906-914.

16. Mueller PA, Oppenheimer DM. The pen is mightier than the keyboard: advantages of longhand over laptop note taking. Psychol Sci. 2014;25(6):1159-1168.

17. Fink JL. Why we banned use of laptops and "scribe notes" in our classroom. Am J Pharm Educ. 2010;74(6):Article 114.

18. Spies AR. Use of laptops and other technology in the classroom. Am J Pharm Educ. 2010;74(8):Article 152a.

19. Brooks D, Pomerantz C, Pomerantz J. ECAR Study of

Undergraduate Students and Information Technology. 2017.

Research report. Louisville, CO: ECAR, October 2017.

20. Gleason BL, Peeters MJ, Resman-Targoff BH, et al. An activelearning strategies primer for achieving ability-based educational outcomes. Am J Pharm Educ. 2011;75(9):Article 186.

21. Blouin RA, Joyner PU, Pollack GM. Preparing for a renaissance in pharmacy education: the need, opportunity, and capacity for change. Am J Pharm Educ. 2008;72(2):Article 42.

22. Hogan $S$, Lundquist LM. The impact of problem-based learning on students' perceptions of preparedness for advanced pharmacy practice experiences. Am J Pharm Educ. 2006;70(4):Article 82. 23. Romero RM, Eriksen SP, Haworth IS. Quantitative assessment of assisted problem-based learning in a pharmaceutics course. Am J Pharm Educ. 2010;74(4):Article 66.

24. McFalls M. Integration of problem-based learning and innovative technology into a self-care course. Am J Pharm Educ. 2013;77(6):Article 127.

25. Lichvar AB, Hedges A, Benedict NJ, Donihi AC. Combination of a flipped classroom format and a virtual patient case to enhance active learning in a required therapeutics course. Am J Pharm Educ. 2016;80(10):Article 175.

26. Prescott WA, Jr., Woodruff A, Prescott GM, Albanese N, Bernhardi C, Doloresco F. Introduction and assessment of a blendedlearning model to teach patient assessment in a doctor of pharmacy program. Am J Pharm Educ. 2016;80(10):Article 176.
27. Persky AM, Pollack GM. Transforming a large-class lecture course to a smaller-group interactive course. Am J Pharm Educ. 2010;74(9):Article 170.

28. Conway SE, Johnson JL, Ripley TL. Integration of team-based learning strategies into a cardiovascular module. Am J Pharm Educ. 2010;74(2):Article 35.

29. Beatty SJ, Kelley KA, Metzger AH, Bellebaum KL, McAuley JW. Team-based learning in therapeutics workshop sessions. Am J Pharm Educ. 2009;73(6):Article 100.

30. Letassy NA, Fugate SE, Medina MS, Stroup JS, Britton ML. Using team-based learning in an endocrine module taught across two campuses. Am J Pharm Educ. 2008;72(5):Article 103.

31. Franklin AS, Markowsky S, De Leo J, Normann S, Black E. Using team-based learning to teach a hybrid pharmacokinetics course online and in class. Am J Pharm Educ. 2016;80(10):Article 171. 32. Bleske BE, Remington TL, Wells TD, et al. A randomized crossover comparison of team-based learning and lecture format on learning outcomes. Am J Pharm Educ. 2016;80(7):Article 120. 33. Frame TR, Gryka R, Kiersma ME, Todt AL, Cailor SM, Chen AM. Student perceptions of and confidence in self-care course concepts using team-based learning. Am J Pharm Educ. 2016;80(3): Article 46.

34. Johnson JF, Bell E, Bottenberg M, et al. A multiyear analysis of team-based learning in a pharmacotherapeutics course. Am J Pharm Educ. 2014;78(7):Article 142.

35. Goldman E, Schroth WS. Perspective: deconstructing integration: a framework for the rational application of integration as a guiding curricular strategy. Acad Med. 2012;87(6):729-734.

36. Cain J, Piascik P. Are serious games a good strategy for pharmacy education? Am J Pharm Educ. 2015;79(4):Article 47. 37. Cain J. A pharmacy elective course on creative thinking, innovation, and TED talks. Am J Pharm Educ. 2016;80(10):Article 170. 38. Steinhardt SJ, Clark JE, Kelly WN, Hill AM. Active-learning strategies for legal topics and substance abuse in a pharmacy curriculum. Am J Pharm Educ. 2017;81(1):Article 4.

39. Friedlander MJ, Andrews L, Armstrong EG, et al. What can medical education learn from the neurobiology of learning? Acad Med. 2011;86(4):415-420.

40. Nelson S, White CF, Hodges BD, Tassone M. Interprofessional team training at the prelicensure level: a review of the literature. Acad Med. 2017;92(5):709-716.

41. Cooke M, Irby DM, Sullivan W, Ludmerer KM. American medical education 100 years after the Flexner report. $N$ Engl J Med. 2006;355(13):1339-1344. 